\title{
Revision of the Psammothidium germainii complex (Bacillariophyta) in the Maritime Antarctic Region
}

\author{
Bart VAN DE VIJVER ${ }^{1,2^{*}}$, Kateřina KopalovÁ ${ }^{3}$ \& Ralitsa ZIDAROVA ${ }^{4}$
}

\author{
${ }^{\prime}$ Botanic Garden Meise, Department of Bryophyta \& Thallophyta, Nieuwelaan 38, B-1860 Meise, Belgium; \\ *Corresponding author e-mail:bart.vandevijver@plantentuinmeise.be \\ ${ }^{2}$ University of Antwerp, Department of Biology, ECOBE, Universiteitsplein 1, B-2610 Wilrijk, Antwerpen, Bel- \\ gium \\ ${ }^{3}$ Charles University in Prague, Faculty of Science, Department of Ecology, Viničná 7, 12844 Prague 2, Czech \\ Republic; e-mail:k.kopalova@hotmail.com \\ 4 "St. Kliment Ohridski" Univeristy of Sofia, Faculty of Biology, Department of Botany, 8 Dragan Tzankov \\ Blvd., 1164 Sofia, Bulgaria; e-mail: zidarova.r@gmail.com
}

\begin{abstract}
Psammothidium germainii is a widespread freshwater monoraphid diatom species in the Antarctic Region. Detailed analysis of the populations in the different parts of the Antarctic Region revealed the presence of several species that were lumped under the name ' $P$. germainii'. The type material of both Achnanthes germainii and Achnanthes ninckei has been investigated to allow a better morphological delimitation of both taxa and to better characterize the new taxa. Two new taxa are proposed: Psammothidium rostrogermainii sp. nov., typical for its rostrate apices and its rather distantly spaced stria pattern, and Psammothidium germainioides sp. nov., formerly identified in Antarctica as Achnanthes ninckei. Both new taxa are illustrated using light and scanning electron micrographs and are compared with similar taxa worldwide. Additionally, two populations of Psammothidium germainii lacking a raphe on the raphevalve are illustrated and discussed.
\end{abstract}

Key words: Psammothidium, monoraphid diatoms, Antarctic Region, type material, morphology

\section{INTRODUCTION}

Psammothidium germainii (MANGUIN) SABBE was originally described as Achnanthes germainii MANGUIN in BourRelly \& MANGuin (1954) from the Iles Kerguelen, a sub-Antarctic archipelago in the South Indian Ocean. SABBE et al. (2003) transferred Achnanthes germainii to the genus Psammothidium as Psammothidium germainii (MANGUIN) SABBE based on the valve and raphe structure. Since the original species description from 1954, it was repeatedly recorded on a large number of Antarctic and sub-Antarctic localities ranging from the sub-Antarctic islands in the South Indian Ocean to the islands in the Maritime Antarctic Region, and Macquarie Island in the South Pacific Ocean (e.g., Oppenheim 1994; VAn de ViJVer et al. 2002; Le CoHU 2005; see Kellogg \& KellogG 2002 for a complete overview).

The original description of Achnanthes germainii in 1954 seems to be based on most likely one or only a few valves, given the very limited valve dimensions of the species (length $19 \mu \mathrm{m}$, width $8.5 \mu \mathrm{m}, 16-18$ striae in $10 \mu \mathrm{m}$ ), provided in Bourrelly \& Manguin (1954).
Previously published illustrations of Psammothidium germainii in OpPENHEIM (1994), VAN DE VIJVER et al. (2002), SABBe et al. (2003), Le CoHu (2005) and EsposiTo et al. (2008) show however a species with a highly variable valve outline and striation pattern. On the islands in the South Indian Ocean, valves typically lack rostrate apices, showing only broadly rounded, weakly protracted apices (VAN DE VIJVER et al. 2002; LE COHU 2005). On the Antarctic Continent and in the Maritime Antarctic Region, illustrated valves usually have distinctly rostrate apices (OpPenheIm 1994; SabBe et al. 2003; Esposito et al. 2008), although on the South Shetland Islands populations with rostrate and non-rostrate apices can also be found (pers. obs.). In addition, on Iles Kerguelen, Le CoHU \& Maillard (1983, pl. III, figs. 62, 63) illustrated valves that clearly belong to Psammothidium germainii, as Achnanthes lapponica var. ninkei (GuermeER \& MANGuIN) ReIMER. The latter species was originally described in 1953 as Achnanthes ninckei GUERMEER \& MANGUIN from the Auvergne (France) and its correct identity was for a long time only known from two drawings in GUERMEER \& MANGUIN (1953). Although described from Europe, several 
records of Achnanthes ninckei were also made in the Antarctic Region (e.g., OpPenheim 1994; see KellogG \& KellogG 2002 for a complete overview) and when illustrated, the observed valves of Achnanthes ninckei showed a remarkably close relation to Psammothidium germainii. Achnanthes ninckei was transferred in 1999 to the genus Eucocconeis as E. ninckei (GUERMEER \& Manguin) Lange-Bertalot (Lange-Bertalot \& GenKAL 1999).

During a survey of the non-marine diatom flora of the South Shetland Islands and James Ross Island, several populations of Psammothidium germainii, showing a large morphological variability have been observed. The present paper revises the different Psammothidium germainii and Eucocconeis ninckei populations from the South Shetland Islands using both light and scanning electron microscopy observations and compares these populations with the type material of Achnanthes germainii and A. ninckei, and with other populations, previously identified as Psammothdium germainii on the islands of the South Indian and South Atlantic Ocean. The original material of $A$. germainii is discussed and two new species are described: $P s a$ mmothidium germainioides sp. nov. and $P$. rostrogermainii sp. nov. Two unusual populations composed of entirely rapheless frustules are likewise discussed. All previously published iconographic data of Psammothidium germainii and Eucocconeis ninckei in the Antarctic and sub-Antarctic regions are investigated and compared to the results of this study.

\section{Materials and Methods}

Samples were collected from various aquatic and terrestrial habitats on the South Shetland Islands (SSI), situated just north of the Antarctic Peninsula $\left(63^{\circ} 00^{\prime} \mathrm{S}, 60^{\circ} 00^{\prime} \mathrm{W}\right)$. The archipelago consists of several larger and many smaller islands and islets, with King George Island $\left(1150 \mathrm{~km}^{2}\right)$ and Livingston Island $\left(972 \mathrm{~km}^{2}\right)$ being the largest. More information on the geology, climate and vegetation can be found in Toro et al. (2007) and Hamsher et al. (2016). Sampling on SSI was done between 2003 and 2013 and sampling methods follow those described in Kopalová \& VAN DE ViJver (2013) and Kopaloví et al. (2014). Details on the physico-chemical analyses ( $\mathrm{pH}$, conductivity, nutrients) can be found likewise in these references.

Diatom samples were prepared following the method described in VAN DER WERFF (1955). Small parts of the samples were cleaned by adding $37 \% \mathrm{H}_{2} \mathrm{O}_{2}$ and heating to $80{ }^{\circ} \mathrm{C}$ for about one hour, followed by addition of $\mathrm{KMnO}_{4}$. After digestion and centrifugation $(3 \times 10$ minutes at $3700 \mathrm{~g})$, the material was diluted with distilled water to avoid excessive concentrations of diatom valves. Cleaned diatom valves were mounted in Naphrax ${ }^{\circledR}$. Samples and slides are stored at the BR-collection, property of the Belgian Federal Government and given on permanent loan to the Botanic Garden Meise (Belgium) and at the Department of Botany, Faculty of Biology, University of Sofia (Bulgaria). The slides were analyzed using an Olympus BX53 microscope, equipped with
Differential Interference Contrast and the Colorview I Soft Imaging System. For scanning electron microscopy (SEM), part of the suspension was filtered through polycarbonate membrane filters with a pore diameter of $1 \mu \mathrm{m}$, pieces of which were fixed on aluminum stubs after air-drying. The stubs were sputter-coated with $20 \mathrm{~nm}$ of Pt-Pd and studied in a Zeiss Ultra microscope at $3 \mathrm{kV}$. Terminology is based on Hendey (1964), Ross et al. (1979) and Round et al. (1990). Stria density was determined in counting striae in $10 \mu \mathrm{m}$, starting near the valve center to one of the apices. For each new taxon, the number of specimens measured at random on the type slide is indicated $(\mathrm{n}=\mathrm{X})$.

For this study, the type material of Achnanthes germainii and Achnanthes ninckei has been investigated:

- Achnanthes ninckei Guermeer \& MANGuIn 1953, slide PC0167805, in the herbarium of the Muséum national d'Histoire Naturelle (MNHN) in Paris

- Achnanthes germainii MANGUIN in Bourrelly \& MANGUIN 1954, slide AD9089, in the herbarium of the Muséum national d'Histoire Naturelle (MNHN) in Paris

For comparison, several populations of Psammothidium germainii observed on the islands in the South Indian Ocean (Prince Edward Islands, Iles Kerguelen and Heard Island) have been analysed using light microscopical observations. The following samples have been investigated.

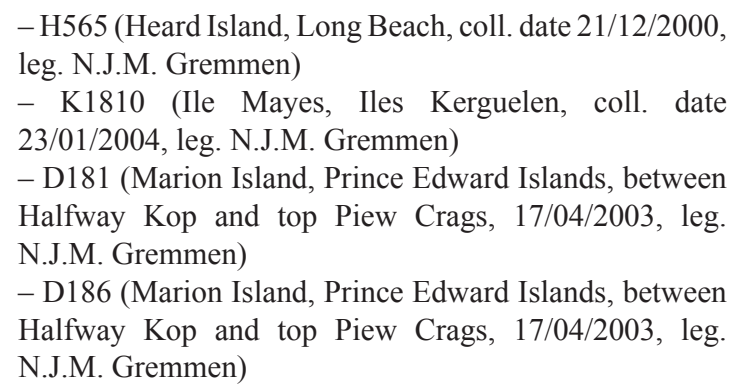

More information regarding these samples can be found in VAN DE VIJVER et al. (2004, 2008).

The biogeography of the (new) taxa was established based on the investigated samples from the South Indian Ocean islands, our observations on the South Shetland Islands during this study and all iconographic material that exists from earlier Antarctic and sub-Antarctic studies. For a better characterization of the ecology of Psammothiidum germainii and its related taxa, all samples in which $P$. germainii was found in the Maritime Antarctic Region, were re-investigated for this study.

\section{Results}

Psammothidium germainii (MAnguIN) SABbe in BouRRElly \& Manguin (1954, p. 22, pl. II, fig. 19a, b) Original description (translated from the original French text by Bourrelly \& MANGuin 1954) (Figs 1-8) Valves elliptic, apices protracted, rostrate with broadly rounded poles, length $19 \mu \mathrm{m}$, width $8.5 \mu \mathrm{m}$. Raphe valve with lanceolate axial area, raphe filiform, central 

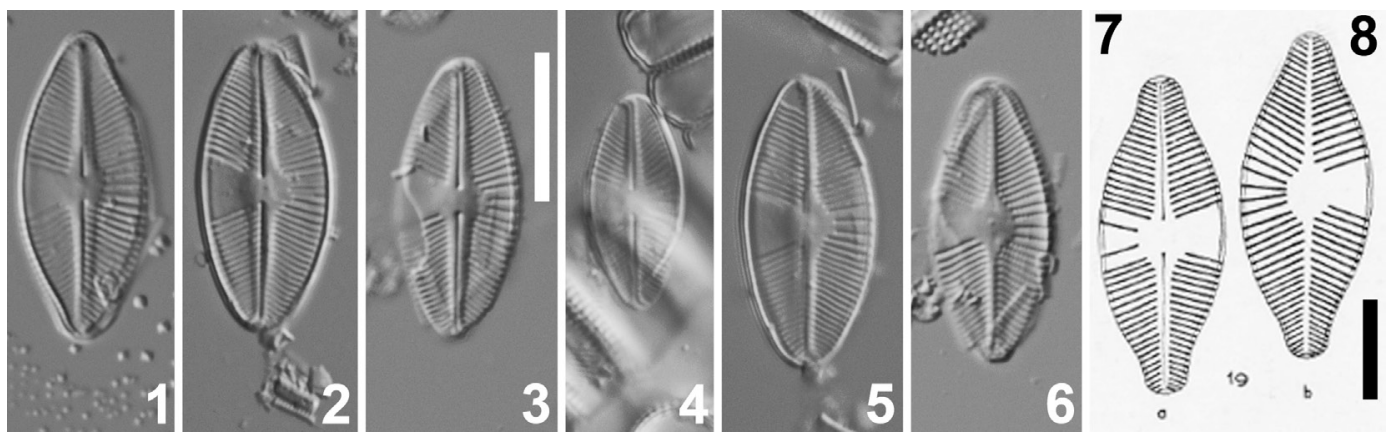

Figs 1-8. Achnanthes germainii MANGuIN: (1-6) LM, pictures taken from the type population (Iles Kerguelen, slide AD9089), single valves showing observed size range; (7-8) line drawings from the original publication (BouRrelLY \& MANGUIN 1954). Scale bars $10 \mu \mathrm{m}$.

area semi-circular, limited on one side by 2 striae, very distantly spaced from each other, widened to the valve margin on the opposite side. Rapheless valve with a narrow, linear longitudinal area, central area also semicircular, but limited on one side by more striae that are less distant, compared to the raphe valve. On both valves, transapical striae about $16-18$ in $10 \mu \mathrm{m}$ in the median part of the valves, about 25 in $10 \mu \mathrm{m}$ towards the apices, radiate and appearing finely punctate.

\section{Morphology of $P$. germainii based on all (sub-)An- tarctic populations (Figs 9-81)}

LM observations (Figs 9-77): Valves elliptic-lanceolate to elliptic with clearly convex margins. Valve apices in larger specimens weakly protracted, sub-rostrate and finally rounded, in smaller specimens apices clearly rounded. Valve dimensions $(n=60)$ : length 12.0-37.0 $\mu \mathrm{m}$, width 6.5-13.5 $\mu \mathrm{m}$. Raphe valve: Axial area lanceolate, narrow becoming very narrow near the apices and gradually widening towards the central area. Central area clearly asymmetrical, variable in size, rhombic (e.g., Figs 24, 25, 56), rounded (e.g., Figs 21, 22, 55) to transversally elliptic (Figs 19, 20, $35,51)$, bordered on one side by several, usually 2-6 irregularly shortened striae, more distantly spaced than the others, and on the opposite side wedge- or bow-tie shaped, expanded, reaching the valve margin. Raphe filiform, weakly undulating. Proximal raphe endings straight, terminating slightly enlarged. Distal raphe fissures hooked in opposite directions. Striae moderately to strongly radiate, sometimes weakly geniculate, more distantly spaced around the central area, and denser toward the apices, (21)22-24 in $10 \mu \mathrm{m}$. Areolae not discernible. Rapheless valve: Axial area narrow, linear to weakly lanceolate, distinctly widening near the central area. Central area asymmetrical, rhombic (e.g., Figs 12, 16, 72), almost rounded (e.g., Fig. 9, 68, 70), to apically elliptic in smaller valves, bordered on one side by shortened striae, slightly more distantly spaced than the others. Occasionally very short striae inserted between the other striae bordering the central area (e.g., Figs 10, 73). On the opposite side, central area wedgeshaped, expanded to the valve margin. Transapical striae in the valve middle weakly to moderately radiate, becoming more radiate and up to strongly radiate near the apices, where more densely spaced, 22-24 in 10 $\mu \mathrm{m}$, finely punctate. Areolae sometimes well visible (e.g., Figs 18, 72).

SEM observations (Figs 78-81): Raphe valve: Raphe located on a weakly raised, thickened sternum. External raphe branches curved. Proximal raphe endings straight, terminating in a small pore. Distal raphe endings hooked, terminating onto the valve face, up to the valve face/mantle junction. Striae only present on the valve face/valve mantle junction, except at the apices, where one areola extending onto the mantle. External areola foramina rounded to transapically elongated and rectangular. Areolae occasionally fused forming larger transapically elongated slits close to the axial area. Areolae ca. 50-60 in $10 \mu \mathrm{m}$. Virgae wider than striae. Internally, raphe straight with straight, inconspicuous proximal raphe endings. Distal raphe endings bent in opposite directions terminating onto weakly developed helictoglossae. Areolae internally mostly transapically rectangular, occluded by individual hymenes. Virgae not raised, slightly wider than striae in the valve middle, becoming equal to and finally narrower than striae at the apices. Rapheless valve: Externally axial area narrow, linear, pseudoraphe indistinct. Striae terminating onto the valve face/mantle junction, composed of slightly transapically elongated areolae, ca. 40-50 in $10 \mu \mathrm{m}$. Areolae of the outermost row close to the valve margin more elongated than the others, almost slitlike. Virgae not raised, wider than the striae. Internally, pseudoraphe present in the form of a very shallow, barely visible, narrow slit-like depression. Areolae internally rectangular, covered by individual hymenes. Virgae slightly raised, almost equal to the striae, with exception of the virgae between the striae enclosing the central area, where virgae are slightly wider than striae.

Ecology: Psammothidium germainii was most often found living in and on bare, oligotrophic to eutrophic, dry to moderately wet soils. Only a few populations were found in open waterbodies and on terrestrial mosses. 

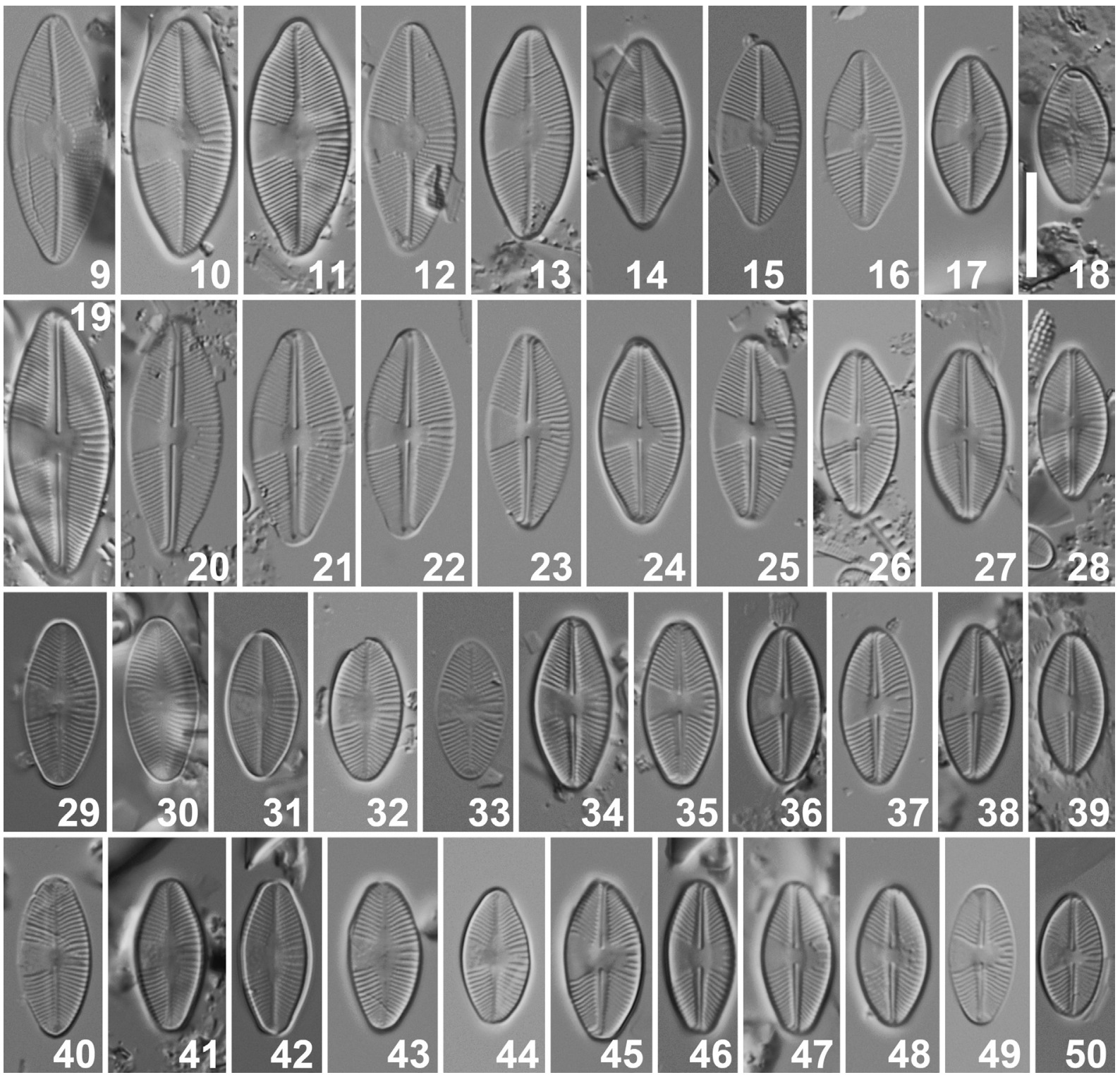

Figs 9-50. Psammothidium germainii (MANGUin) SABBE: (9-28) LM, pictures taken from various populations on the Prince Edward islands, single valves showing observed size range with Figs 9-18 representing rapheless valves and Figs 19-28 showing raphe valves; (29-39) LM, pictures taken from various populations on Iles Kerguelen, single valves showing observed size range with Figs 29-33 representing rapheless valves and Figs 34-39 showing raphe valves; (40-50) LM, pictures taken from various populations on Heard Island, single valves showing observed size range with Figs 40-44 representing rapheless valves and Figs 45-50 showing raphe valves. Scale bars $10 \mu \mathrm{m}$.

Confirmed distribution: South Indian Ocean islands (Ile Amsterdam, Prince Edward Islands, Iles Crozet, Iles Kerguelen, Heard Island), Macquarie Island, South Shetland Islands (Deception Island, King George Island, Nelson Island, Livingston Island), James Ross Island.

\section{Description of new taxa}

Psammothidium rostrogermainii sp. nov. (Figs 82107)

\section{Description}

Light microscopy (Figs 82-103): Valves strictly elliptic with clearly convex margins and clearly protracted, rostrate apices. Apices in the smallest valves more or less subrostrate. Valve dimensions $(n=40)$ : length
8.5-24.0 $\mu \mathrm{m}$, width 5.0-9.0 $\mu \mathrm{m}$. Raphe valve: Axial area narrow, lanceolate, very narrow near the apices and gradually widening towards the central area. Central area rounded (e.g., fig. 86) to rhombic (e.g., fig. 82 ), asymmetrical, unilaterally expanded to one of the valve margins and bordered by usually $2-4$ shortened striae on the opposite side. Raphe weakly undulating with almost inconspicuous, straight proximal raphe endings. Distal fissures short, bent in opposite directions. Striae strongly radiate, clearly distantly spaced around the central area; denser, geniculate, and more radiate near the apices, (16)18-22 in $10 \mu \mathrm{m}$. Areolae not discernible. Rapheless valve: Axial area very narrow, linear, distinctly widening near the central area. Central area rhombic, asymmetrically expanded to one of the 

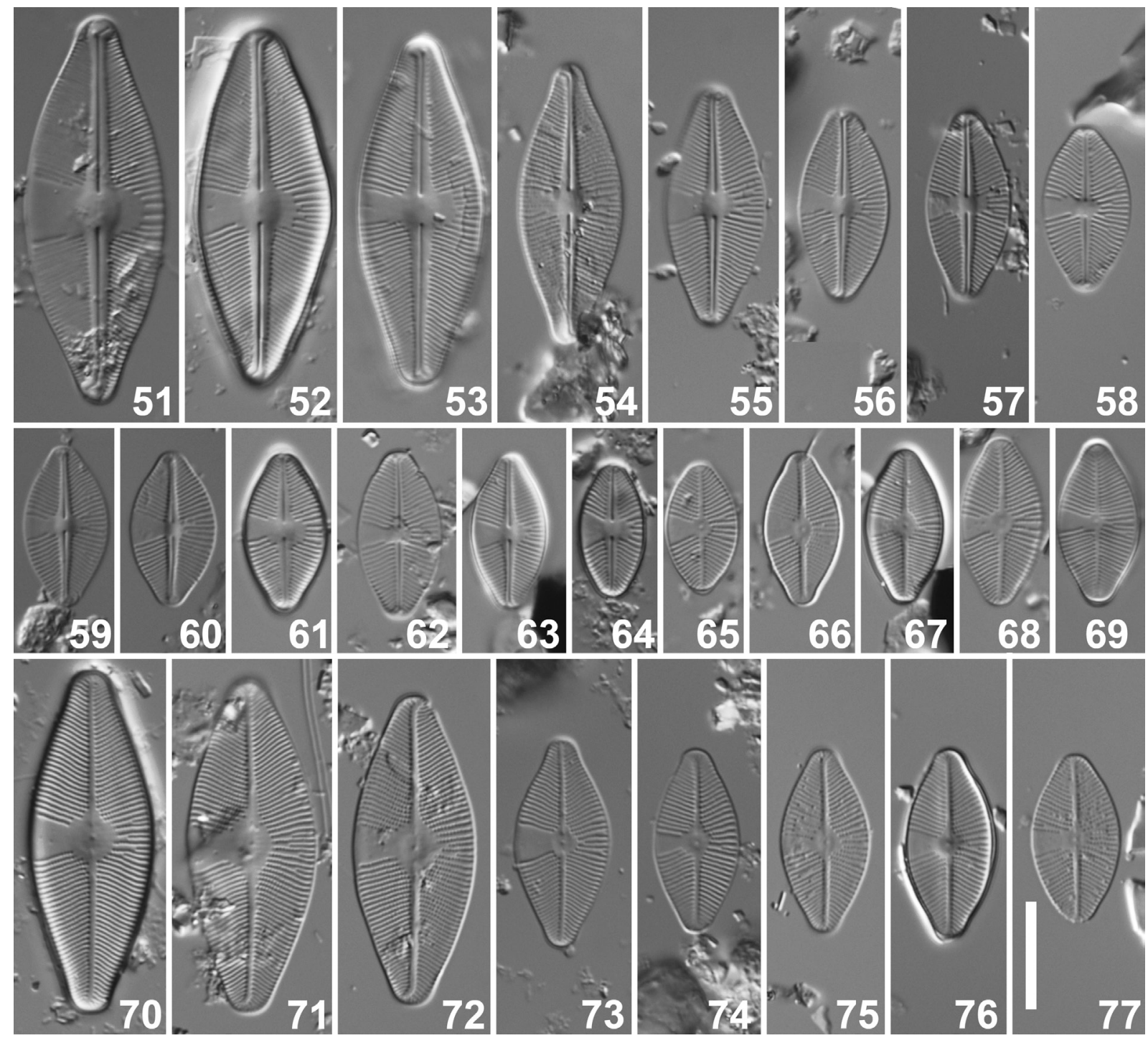

Figs 51-77. Psammothidium germainii (MANGUIN) SABBE: LM, pictures taken from various populations on Livingston Island, single valves showing observed size range with Figs 51-64 representing raphe valves and Figs 65-77 showing rapheless valves. Scale bars $10 \mu \mathrm{m}$.

valve margins, bordered by regularly shortened striae. Occasionally, very short striae inserted between the central striae (e.g., Figs 95, 96, 98). Striae moderately to strongly radiate throughout, more distantly spaced around the central area, denser and weakly geniculate towards the apices, 18-22 in $10 \mu \mathrm{m}$. Areolae not discernible.

Scanning electron microscopy (Figs 104-107): Raphe valve: Raphe straight, located on a slightly raised, thickened sternum (Fig. 105). Proximal raphe endings straight, simple (Fig. 105). Distal fissures simple, terminating on the valve face near the last striae, shortly bent in opposite directions (Figs 105, 107). Striae uniseriate, terminating at the valve face/valve mantle junction. Each stria composed of slightly apically elongated areolae, ca. 60-65 in $10 \mu \mathrm{m}$. Areolae of the first row near the axial area slightly larger than the others. Virgae almost not or only weakly raised, about 1.5-2 times wider than striae (Fig. 105). Rapheless valve: Externally, axial area narrow, pseudoraphe weakly developed (Fig. 104). Scattered small, shallow, pointlike depressions present on the expanded to the margin side of the central area. Striae uniseriate, terminating on the valve face/valve mantle junction, composed of mostly weakly apically elongated areolae, becoming smaller and rounded near the apices, ca. 55-60 in 10 $\mu \mathrm{m}$. Areolae of the first row next to the axial area slightly larger than the others (Fig. 104). Virgae not, or only weakly raised, ca. 1.5-2 times wider than striae. Internally, areolae almost rectangular, occluded by individual hymens (Fig. 106). Virgae not raised, about 1-2 times wider than striae.

Holotype: BR-4440 (Botanic Garden Meise, Belgium)

Isotypes: PLP-296 (University of Antwerp, Belgium), BRM-ZU10/66 (HustedT Collection, Bremerhaven, 

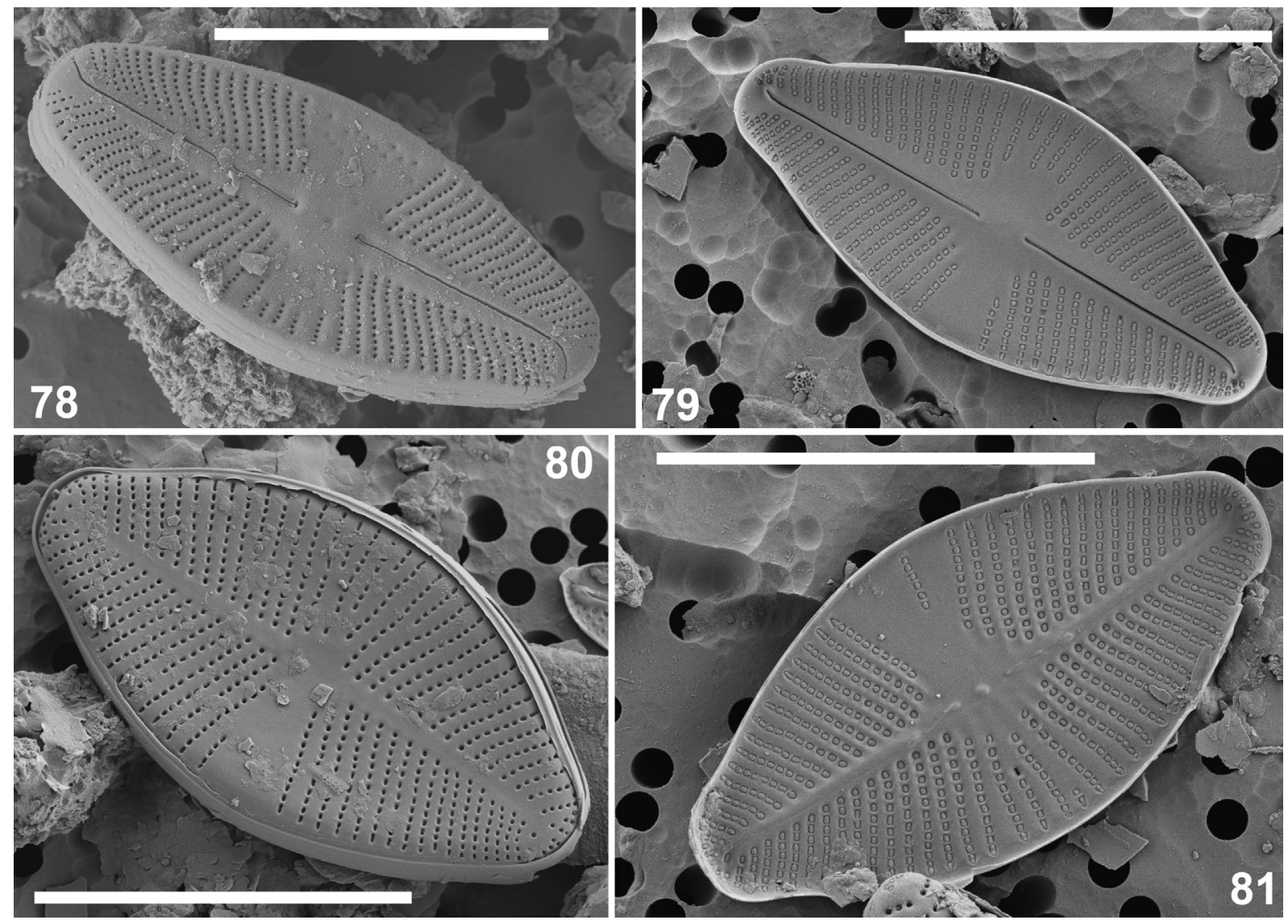

Figs 78-81. Psammothidium germainii (ManguIn) SABBE: (78-81) SEM, (78) external whole valve raphe valve view, (79) interior whole raphe valve view, (80) external whole valve rapheless valve view, (81) interior whole rapheless valve view. Scale bars $10 \mu \mathrm{m}$.

Germany)

Type locality: Byers Peninsula, sample BY042, Livingston Island, South Shetland Islands, (leg. B. VAN DE VIJVER, coll. date: 14/01/2009)

Etymology: The specific epithet refers to the close resemblance to $P$. germainii and the rostrate apices.

Ecology: Psammothidium rostrogermainii has been often observed together with other species of the Psammothidium germainii - complex in a variety of terrestrial habitats. It has been found most abundantly living on dry to wet mosses, moist and wet soils with a $\mathrm{pH}$ range of 5.9 to 7.4 , and also on the bottom of a small lake, having an almost neutral $\mathrm{pH}$ (7.5) and a conductivity of $107 \mu \mathrm{S}$.

Confirmed distribution: Psammothidium rostrogermainii was with certainty observed on several islands of the South Shetland Archipelago (Livingston Island, King George Island, Nelson Island, Dart Island and Deception Island) and James Ross Island. A survey of the existing iconographic material in the literature shows that it is much more widespread in the Antarctic region, but usually identified as $P$. germainii. Records could be verified based on illustrated valves from Signy Island (South Orkney Islands) (as Achnanthes germainii, OppenheIm 1994, figs 37-39), King George Island (South Shetland Islands) (NogA \& OLECH 2004, fig. 3a), Antarctic Peninsula (Vinocur \& Pizarro 2005, reported as Navicula clementis Grunow, fig. 3(15); ZIDAROVA 2008, Pl. III, fig. 16, Pl. V, fig. 5; Watcham 2010, fig. 22) and the Antarctic Continent (Esposito et al. 2006, fig. 1d, as Psammothidium germainii var. \#1; SABBE et al. 2003, figs 11-12 and Esposito et al. 2008, figs 66-72, as Psammothidium germainii ).

Psammothidium germainioides sp. nov. (Figs 108138)

\section{Description}

Light microscopy (Figs 108-134): Valves ellipticlanceolate with clearly convex margins and rounded, slightly sub-rostrate apices. Valve dimensions $(\mathrm{n}=27)$ : length $10.5-16.0 \mu \mathrm{m}$, width $5.0-6.5 \mu \mathrm{m}$. Raphe valve: Axial area very narrow, almost linear to weakly lanceolate, slightly enlarged towards the central area. Central area large, rounded (e.g., figs 108, 115) to broadly bowtie shaped (e.g., figs 110, 114), asymmetrical, strongly expanded toward one of the margins, and not reaching the margin on the opposite side, where bordered by several short striae of irregular length. Raphe almost straight. Proximal raphe endings straight, relatively distant, slightly expanded. Distal fissures elongated, 

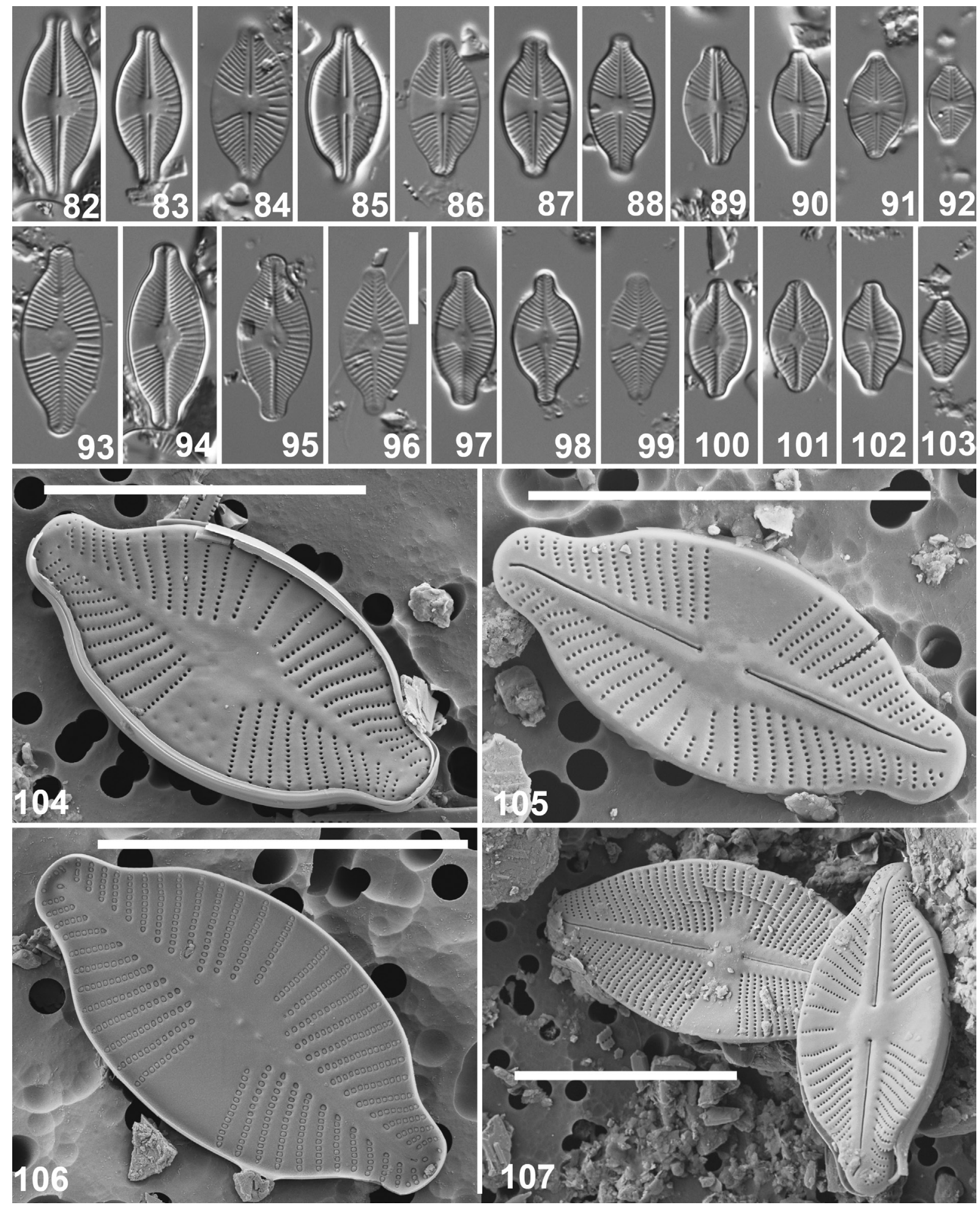

Figs 82-107. Psammothidium rostrogermainii sp. nov.: (82-103) LM, pictures taken from the type population (Byers Peninsula, sample BY042, Livingston Island, South Shetland Islands), single valves showing observed size range; (104-107) SEM, (104) external whole rapheless valve view, (105) interior whole rapheless valve view, (106) external whole raphe valve view, (107) external whole raphe valve view of Psammothidium rostrogermainii (lower right) and P. germainii (upper left). Scale bars $10 \mu \mathrm{m}$.

hooked in opposite directions. Transapical striae moderately radiate throughout, straight, never geniculate, 26-30 in $10 \mu \mathrm{m}$. Areolae not discernible. Rapheless valve: Axial area very narrow. Pseudoraphe distinct. Central area variable in shape and size, almost rounded (e.g., figs 125, 131) to bow-tie shaped (e.g., fig. 127), bordered by irregularly shortened striae on both sides, or asymmetrically enlarged, reaching the margin on one of the sides, and bordered by short striae on the opposite side. Irregular depressions visible in the central 


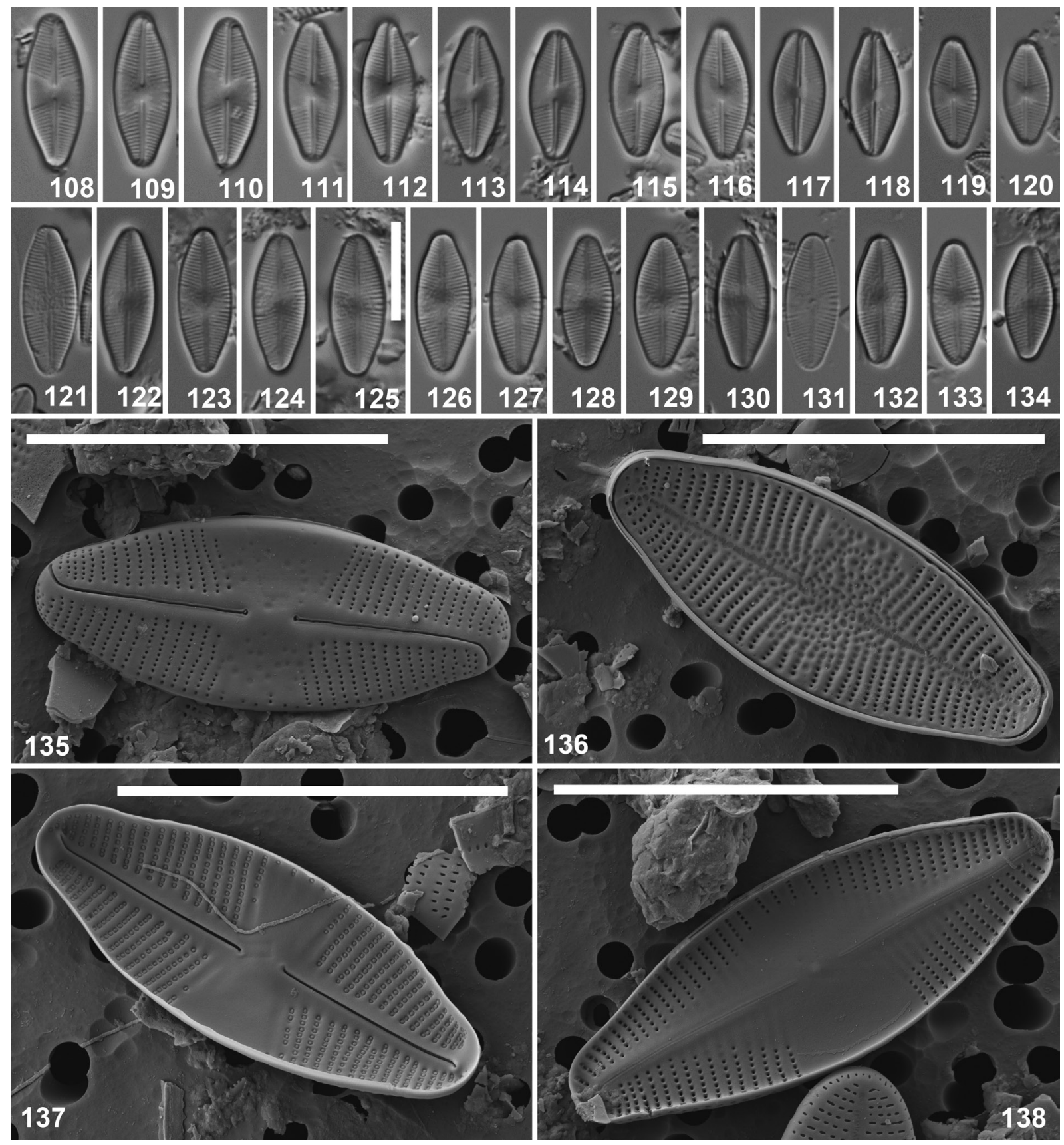

Figs 108-138. Psammothidium germainioides sp. nov.: (108-134) LM, pictures taken from the type population (Clarke's Nunatak, Byers Peninsula, sample BYM043, Livingston Island, South Shetland Islands), single valves showing observed size range; (135-138) SEM, (135) external whole rapheless valve view, (136) interior whole rapheless valve view, (137) external whole raphe valve view, (138) interior whole raphe valve view. Scale bars $10 \mu \mathrm{m}$.

area. Transapical striae moderately radiate throughout, straight, not geniculate, more distantly spaced around the central area, denser toward the apices, $27-28$ in 10 $\mu \mathrm{m}$. Areolae not discernible.

Scanning electron microscopy (Figs 135-138): Raphe valve: External raphe located on a slightly raised, thickened sternum (Fig; 135). Raphe weakly undulating. Proximal raphe endings straight and pore-like expanded (Fig. 135). Distal endings elongated, hooked, terminating onto the mantle below the last stria (Fig.
135). Central area large, bow-tie shaped, expanded to the margin at one side and bordered by short striae of 1-2 areolae on the other side. Scattered, irregularly placed, shallow, rounded depressions present in the central area. Striae uniseriate, straight, occasionally 1-2 striae closer to the central area, geniculate, not continuing beyond the valve face/valve mantle junction, with the exception of the striae near the apices, where a row of areolae of the last 3-4 striae extends onto the mantle (Fig. 135). Each stria composed of small, rounded areolae, 60-70 in $10 \mu \mathrm{m}$. Areolae onto 
the valve face/mantle junction slightly larger than the others, as well as some of the areolae, bordering the axial area. Virgae not raised, about twice as wide as the striae. Internal raphe straight (Fig. 137). Proximal endings shortly bent in opposite directions. Distal raphe endings finishing onto helictoglossae, bent opposite to the proximal raphe endings and in opposite directions one to another. Areolae internally almost rectangular, occluded by individual hymenes. Virgae slightly raised, wider than the striae in the most part of the valve, becoming equal to and finally narrower than striae at the apices (Fig. 137). Rapheless valve: Pseudoraphe distinct both externally and internally (Figs 136, 138). Externally, pseudoraphe formed by many irregular depressions in the axial area. In the central area large number of scattered rounded depressions present. About half of the areolae of the striae, bordering the central area covered by a silica layer (Fig. 136). Striae uniseriate, composed of rounded to weakly apically elongated areolae, ca. 60 in $10 \mu \mathrm{m}$. Last areola near the margin sometimes smaller than the others. Virgae raised, almost equal to the striae or slightly wider than the striae, except the virgae between the striae bordering the central area, that are about twice as wide. Internally, pseudoraphe present as a shallow, narrow, slightly curved slit, located on a raised sternum and a small, distinct, rounded central nodule (Fig. 138). Axial and central area forming an even, lanceolate hyaline area on the entire valve axis. Areolae internally rectangular. Virgae wider than the striae in most of the valve, equal to and finally narrower than the striae near the apices, where virgae could be slightly raised (Fig. 138).

\section{Holotype: BR-4441 (Botanic Garden Meise, Bel- gium).}

Isotypes: PLP-297 (University of Antwerp, Belgium), BRM-ZU10/67 (HustedT Collection, Bremerhaven, Germany)

Type locality: Clarke's Nunatak, Byers Peninsula, sample BYM043, Livingston Island, South Shetland Islands, (leg. B. VAN DE VIJVER, coll. date: 12/01/2009) Etymology: The specific epithet refers to the close resemblance to $P$. germainii.

Ecology: Psammothidium germainioides was not often observed and usually with not large populations on moist soil under moss vegetation covers, on moist mosses near bird colonies and on the bottom of a small creek, covered by Prasiola crispa, having a neutral $\mathrm{pH}$ (7.00) and a specific conductance value of $117 \mu \mathrm{S}$.

Confirmed distribution: Signy Island, South Orkney Islands (as Achnanthes ninckei, OPPENHEIM 1994, figs 17-20, 54-57) and most major islands of the South Shetland Islands (King George Island, Nelson Island and Livingston Island).
Psammothidium germainii, entirely rapheless populations (Figs 139-163)

On the Prince Edward Islands (South Indian Ocean) and on Livingston Island (South Shetland Islands, South Atlantic Ocean), two populations of Psammothidium germainii have been observed where both valves of the same frustule lack a raphe. Both populations show a clear difference in valve outline. The population of the Prince Edward Islands (Figs 154-163) has a typical diamond-shaped valve outline, whereas the Livingston Island population (Figs 139-153) is more rhombiclanceolate. Unfortunately, the Prince Edward Islands population is very small and no valves were observed in the SEM, so a comparison of the ultrastructure between both populations was not possible.

In LM, the Livingston Island rapheless population does not show large differences with the rapheless valves of the normal $P$. germainii populations. In the SEM, on the other hand, it is clear that the sternum in both valves is entirely filled with silica (Figs 150, 151). Moreover, the entire valve is very heavily silicified with small, irregular ridges bordering the external areolar foramina. Small silica plates are extending from these ridges covering partly the areolae (Figs 150, 152). A few valves have been observed that show similar heavily silicified valves with the typical silica outgrowths around and on the areolae (Figs 149, 153) but that have a slightly more primitive raphe, compared to the normal $P$. germainii populations (compare Figs 153 \& 78).

\section{Discussion}

It is clear that the generally accepted idea of Psammothidium germainii needed a serious revision. The results of this revision indicated clearly that not one but at least three taxa were regularly identified as $P$. germainii. Based on their morphology, these three taxa can be clearly separated from each other. The morphological analysis of the type material of Achnanthes germainii and the comparison with all populations observed on the islands in the South Indian Ocean pointed out that all these populations, although from different islands, showed a rather low morphological variability. Given the similarity with the type of $A$. germainii, these populations can be identified with certainty as Psammothidium (Achnanthes) germainii. The only marked difference between the South Indian Ocean populations are the valve dimensions, with the populations observed on the Prince Edward Islands being clearly larger than the populations on the other islands.

Part of the populations on the investigated localities in the South Atlantic Ocean (South Shetland Islands, James Ross Island) presented the same morphology as the South Indian Ocean Islands and can therefore likewise be identified as $P$. germainii. The same 

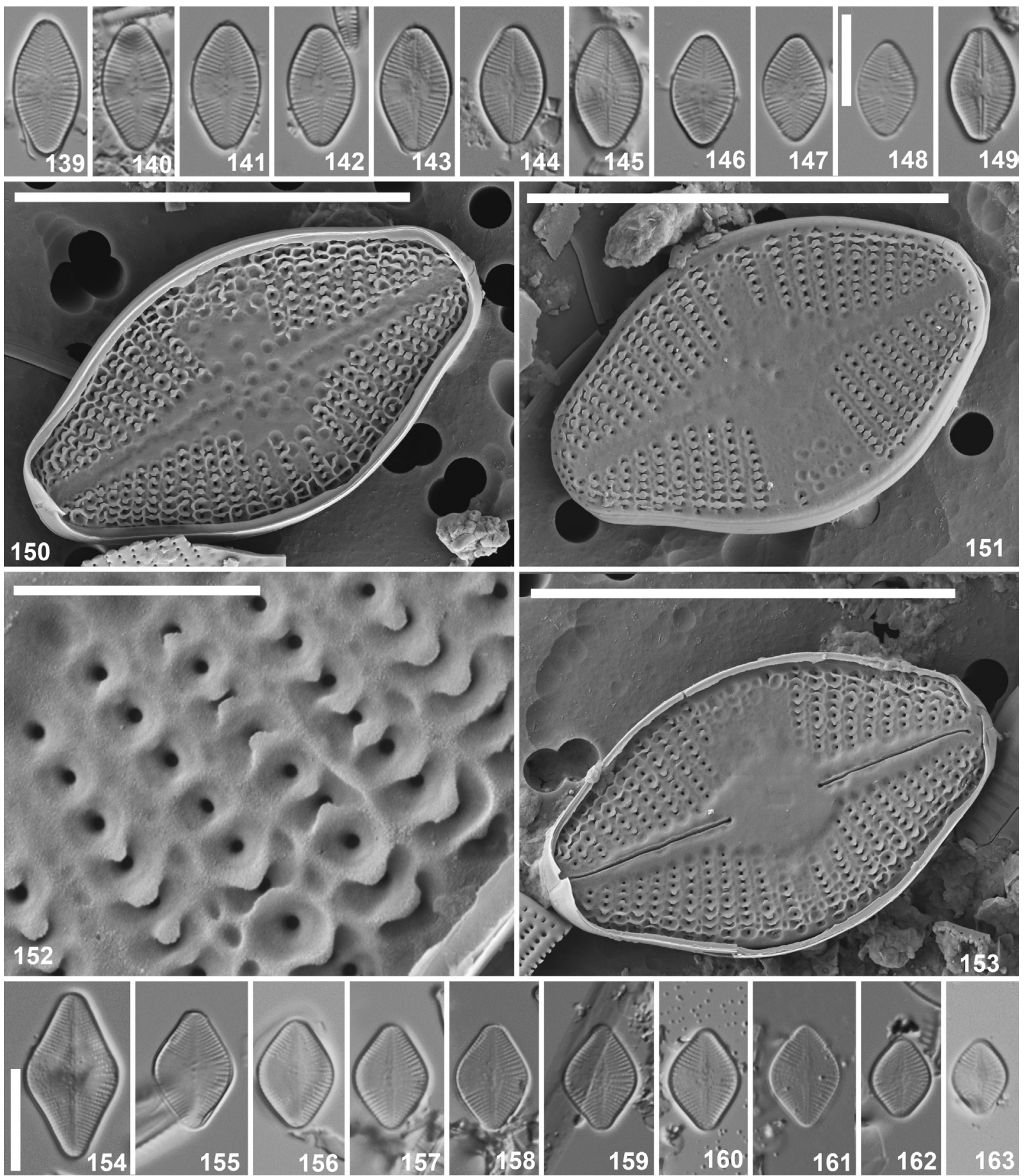

Figs 139-163. Psammothidium germainii (MANGUIN) SABBE, populations having frustules with only rapheless valves: (139-149) LM, pictures taken from the Livingston Island population (South Shetland Islands), single valves showing observed size range; (150-153) SEM, (150-151) external whole rapheless valve views, (152) external detail of the areolae with the rimmed edges, (153) external whole valve view of a valve with a reduced raphe; (154-163) LM, pictures taken from the Prince Edwards Islands population. Scale bars $10 \mu \mathrm{m}$.

morphometrical variability can be observed within the South Atlantic populations as within the South Indian populations. The morphological analysis of all these populations and their comparisons with the few valves observed in the type material of Achnanthes germainii allowed for a better morphological and morphometric description of $P$. germainii.

On the South Shetland Islands (own observations), James Ross Island (own observations) and the
Antarctic Continent (e.g., SABBE et al. 2003), a typically rostrate form was observed, which is here described as a separate species, $P$. rostrogermainii sp. nov. In samples where both $P$. germainii and $P$. rostrogermainii were present, a morphological continuum from germainii to rostrogermainii was never observed. Besides the clear difference in valve outline, consistent throughout the entire cell cycle, the new species also differed from $P$. germainii in having a lower stria den- 

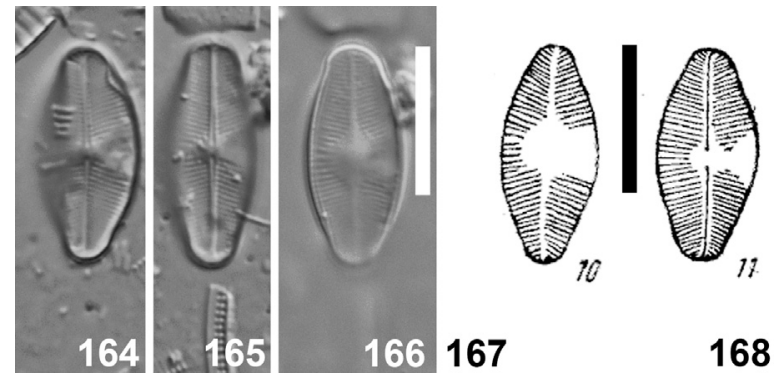

Figs 164-168. Achnanthes ninckei GuERMEER \& MANGUIN: (164-166) LM, pictures taken from the type population (slide PC0167805), single valves showing observed size range; (167-168) line drawings from the original publication (GUERMEER \& MANGUIN 1953). Scale bars $10 \mu \mathrm{m}$.

sity and more distantly spaced striae near the central area in the raphe valve. Figure 107 shows the raphe valves of both taxa on the same picture highlighting the morphological differences between both. There are hardly any other strictly rostrate Psammothidium taxa known in the Antarctic Region and more in general even worldwide. Psammothidium rechtensis (LECLERCQ) LANGE-BERTALOT shows slightly rostrate valves but differs in striation pattern, lacking the asymmetrical fascia, and has a typical apical curving of the valve, which is almost absent in P. germainii (LANGE-BERTALOT \& KRAMmer 1989). Achnanthidium australexiguum VAn de ViJver and A. exiguum (Grunow) CZARnecki have both a clear fascia on the raphe valve, almost parallel valve margins, more parallel striae and an almost completely absent central area on the rapheless valve, greatly reducing possible confusion with $P$. rostrogermainii (TAYLOR et al. 2014).

The third species, $P$. germainioides sp. nov., has been probably reported under different names in the Antarctic literature. Kellogg \& KellogG (2002) listed several records of Eucocconeis ninckei, E. laevis (OESTRUP) LANGE-BERTALOT and E. quadratarea (Oestrup) Lange-Bertalot. On Livingston Island and James Ross Island, several populations of $P$. germanioides were initially identified as $E$. ninckei since the exact morphology of the type of the latter species was not known. Comparison of the valves found in the type (Figs 164-168) with the different observed populations and the illustrations found in the Antarctic literature (e.g., OPPENHEIM 1994, figs 17-20) rejected however the possible conspecificity with E. ninckei. Psammothidium germainioides shows some resemblance to Psammothidium investians (CARTER) BukhtiYARova and $P$. aretasii (Manguin) Le Cohu. Psammothidium investians, described by CARTER from the Tristan da Cunha archipelago (CARTER 1966) in the South Atlantic Ocean has elliptical to lanceolate-elliptical valves lacking any protracted apices. The species possesses on both valves a smaller central area than $P$. germainioides and a higher stria density (up to 34 in $10 \mu \mathrm{m}$ ) (VAN DE VIJVER et al. 2002). Psammothidium aretasii on the other hand has more elongated, lanceolate valves with acutely rounded, protracted apices, giving the species a more slender outlook than $P$. germainioides. The central area in the rapheless valve of $P$. aretasii is larger and clearly elliptical on one side compared to the central area in $P$. germainioides (VAN DE VIJVER et al. 2002). Psammothidium germainii s.s. can be separated from $P$. germainioides based on the larger valve width (above $6.5 \mu \mathrm{m}$ in $P$. germainii and less than $6.5 \mu \mathrm{m}$ in $P$. germainioides), as well as the smaller stria density (up to 24 striae in $10 \mu \mathrm{m}$ in $P$. germainii vs. more than 26 striae in $10 \mu \mathrm{m}$ in $P$. germainioides). Other differences include the comparatively larger central area of both raphe and rapheless valves of $P$. germainioides and the higher number of areolae ( $\geq 60$ vs. less than 60 in 10 $\mu \mathrm{m}$ in $P$. germainii).

The entirely rapheless populations of $P$. germainii on Livingston Island and the Prince Edward Islands are quite unusual. Both valves of the same frustule presented a raphe sternum that was completely occluded with silica. Raphe loss has been observed in other raphid diatom species but was usually the result of colony formation such as in Diadesmis gallica W.SMiтH (Cox 2006), together with the presence of spines. On the South Indian Ocean islands Frankophila maillardii (Le Cohu) Lange-Bertalot shows a clear distinction between valves with a raphe, lacking spines and valves with raphe vestiges and well developed spines linking the valves into long chains (VAN DE VIJVER et al. 2002). However, colonies of $P$. germainii have never been observed and the silica ridges between the areolae can hardly be called spines. Since we were unable to find valves from the Prince Edward Islands population in the SEM, it is unclear whether both rapheless populations are indeed similar to each other and whether they are truly conspecific with $P$. germainii. On Livingston Island, the rapheless population was found in the same sample as the normal $P$. germainii. But since both rapheless populations were only observed in one sample on each island respectively, and no other records of these rapheless valves could be found in literature, it is more likely that they represent a local (possibly teratogenic) aberration that led to the filling of the raphe with silica, and not (a) separate species. We refrained therefore from describing these populations as new species at present.

\section{ACKNOWLEDGEMENTS}

This study was supported as a long-term research development project RVO no. 67985939. Samples on Byers Peninsula were taken in the framework of the IPY-Limnopolar Project POL2006-06635 (Ministerio de Ciencia y Tecnología, Spain). Observations on Deception Island, King George Island and Nelson Island were done within ДМУ 03-63 (Bulgarian Science Fund). Part of this research was funded within the FWO project G.0533.07 and by the BELSPO project CCAMBIO. Dr. ALEX BALL and the staff of the IAC laboratory at the Natural History Museum are thanked for their help with the scanning electron microscopy. Dr. Niek Gremmen is thanked for sampling at Heard Island and the Prince Edward Islands. Dr. Line LE 
GALL of the Muséum national d'Histoire naturelle (MNHN) in Paris is thanked for borrowing us the type slides or Achnanthes germainii and $A$. ninckei.

\section{REFERENCES}

Bourelly, P. \& Manguin, E. (1954): Contribution a la Flore Algale d'eau Douce des Iles Kerguelen. - Memoires de l'Institut Scientifique de Madagascar, Séries B., Vol. V, 5-58+11 pls.

CARTER, J.R. (1966): Some freshwater diatoms from Tristan da Cunha and Gough Island. - Nova Hedwigia 11: 443-481.

Cox, E.J. (2006): Raphe loss and spine formation in Diadesmis gallica (Bacillariophyta) - an intriguing example of phenotypic polymorphism in a diatom. - Nova Hedwigia Beiheft 130: 163-176.

Esposito, R.M.M.; Horn, S.L.; McKnight, D.M.; Cox, M.J.; Grant, M.C.; Spaulding,S.A.; Doran, P.T. \& Cozzetto, K.D. (2006): Antarctic climate cooling and response of diatoms in glacial meltwater streams. - Geophysical Research Letters 33: L07406. DOI:10.1029/2006GL025903

Esposito, R.M.M.; Spaulding, S.A.; McKnight, D.M.; Van de Vijver, B.; Kopalová, K.; Lubinski, D.; Hall, B. \& Whittaker, T. (2008): Inland diatoms from the McMurdo Dry Valleys and James Ross Island, Antarctica. - Botany 86: 1378-1392.

Guermeer, P. \& Manguin, E. (1953): Note sur quelques Diatomées rares ou nouvelles. - Österreichische Botanische Zeitschrift 100: 540-547.

Hendey, N.I. (1964): An introductory account of the smaller algae of British coastal waters. Part V. Bacillariophyceae (Diatoms). - 317pp. + 44 plates, her Majesty's Stationery Office, London.

KellogG, T.B. \& Kellogg, D.E. (2002): Non-marine and littoral diatoms from Antarctic and Subantarctic regions. Distribution and updated taxonomy. - Diatom Monographs 1: 1-795.

Kopalová, K. \& Van de ViJver, B. (2013): Structure and ecology of freshwater diatom communities of Byers Peninsula (Livingston Island, South Shetland Islands). - Antarctic Science 25: 239-253.

Kopalová, K.; Ochyra, R.; Nebalová, L. \& Van de Vijver, B. (2014): Moss-inhabiting diatoms from two contrasting Maritime Antarctic islands. - Plant Ecology and Evolution 147: 67-84.

Hamsher, S.; Kopalová, K.; Kociolek, J.P.; Zidarova, R. \& VAn de ViJver, B. (2016): The genus Nitzschia on the South Shetland Islands and James Ross Island. - Fottea (in press).

Lange-Bertalot, H. \& Genkal, S.I. (1999): Diatoms from Siberia I - Islands in the Arctic Ocean (YugorskyShar Strait). - Iconographia Diatomologica 6: 1-303.

Lange-Bertalot, H. \& Krammer, K. (1989): Achnanthes, eine Monographie der Gattung. - Bibliotheca Diatomologica 18: 1-193.

Le Cohu, R. (2005): Révision des principales espèces dulçaquicoles d'Achnanthales (Bacillariophyta) des îles subantarctiques de Kerguelen. - Algological Studies 116: 79-114.

Le Cohu, R. \& MaIllard, R. (1983): Les diatomées monoraphidées des îles Kerguelen. - Annales de Limnologie
19: $143-167$.

Noga, T. \& Olech, M.A. (2004): Diatom communities in Moss creek (King George Island, South Shetland Islands, Antarctica) in two summer seasons: 1995/96 and 2001/02. - Oceanological and Hydrobiological Studies 33: 103-120.

Oppenheim, D.R. (1994): Taxonomic studies of Achnanthes (Bacillariophyta) in freshwater maritime antarctic lakes. - Canadian Journal of Botany 72: 1735-1748.

Ross, R.; Cox, E.J.; Karayeva, N.I.; Mann, D.G.; Paddock, T.B.B.; Simonsen, R. \& Sims, P.A. (1979): An amended terminology for the siliceous components of the diatom cell. - Nova Hedwigia, Beih. 64: 513-533.

Round, F.E.; Crawford, R.M. \& Mann, D.G. (1990): The diatoms. Biology and morphology of the genera. 747 pp., Cambridge University Press, Cambridge.

Sabbe, K.; Verleyen, E.; Hodgson, D.A.; Vanhoutte, K. \& VYVERMAN, W. (2003): Benthic diatom flora of freshwater and saline lakes in the Larsemann Hills and Rauer Islands, East Antarctica. - Antarctic Science 15: 227-248.

Taylor, J.C.; Cocquyt, C.; Karthick, B. \& Van de Vijver, B. (2014): Analysis of the type of Achnanthes exigua Grunow (Bacillariophyta) with the description of a new Antarctic diatom species. - Fottea 14: 43-51.

Toro, M.; Camacho, A.; Rochera, C.; Rico, E.; Bañón, M.; Fernández-Valiente, E.; Marco, E.; Justel, A.; AvENDAÑo, M.C.; ARIOSA, Y.; Vincent, W.F. \& QuesadA, A. (2007): Limnological characteristics of the freshwater ecosystems of Byers Peninsula, Livingston Island, in maritime Antarctica. - Polar Biology 30: 635-649.

Van de Vijver, B.; Frenot, Y \& Beyens, L. (2002): Freshwater diatoms from Ile de la Possession (Crozet Archipelago, Subantarctica). - Bibliotheca Diatomologica 46: $1-411$.

Van de Vijver, B.; Beyens, L.; Vincke, S. \& Gremmen, N. (2004) Moss-inhabiting diatom communities from Heard Island, sub-Antarctic. - Polar Biology 27: $532-543$

Van de ViJver, B.; Gremmen, N.J.M. \& Smith, V. (2008) Diatom communities from the sub-Antarctic Prince Edward Islands: diversity and distribution patterns. Polar Biology 31: 795-808.

VAN DER WERFF, A. (1955): A new method for cleaning and concentrating diatoms and other organisms. - Verhandlungen der Internationalen Vereinigung für theoretische und angewandte Limnologie 12: 276-277.

Vinocur, A. \& Pizarro, H. (1995): Periphyton flora of some lotic and lentic environments of Hope Bay (Antarctic Peninsula). - Polar Biology 15: 401-414.

Waтснам, E.P. (2010): Late Quaternary relative sea level change in the South Shetland Islands, Antarctica [PhD thesis]. - 269 pp., Durham University. Durham. Available on-line: http://etheses.dur.ac.uk/485/

Zidarova, R.P. (2008): Algae from Livingston Island (S Shetland Islands): a check-list. - Phytologia Balcanica 14: 19-35.

(C) Czech Phycological Society (2016)

Received January 20, 2016

Accepted March 21, 2016 